\title{
Interactions of Phytophthora capsici with Resistant and Susceptible Pepper Roots and Stems
}

\author{
Amara R. Dunn and Christine D. Smart
}

Plant Pathology and Plant-Microbe Biology Section, School of Integrative Plant Sciences, Cornell University, Geneva, NY. Accepted for publication 12 May 2015.

\begin{abstract}
Dunn, A. R., and Smart, C. D. 2015. Interactions of Phytophthora capsici with resistant and susceptible pepper roots and stems. Phytopathology 105:1355-1361

Using host resistance is an important strategy for managing pepper root and crown rot caused by Phytophthora capsici. An isolate of $P$. capsici constitutively expressing a gene for green fluorescent protein was used to investigate pathogen interactions with roots, crowns, and stems of Phytophthora-susceptible bell pepper 'Red Knight', Phytophthora-resistant bell pepper 'Paladin', and Phytophthora-resistant landrace Criollos de Morelos 334 (CM-334). In this study, the same number of zoospores

attached to and germinated on roots of all cultivars 30 and $120 \mathrm{~min}$ postinoculation (pi), respectively. At 3 days pi, significantly more secondary roots had necrotic lesions on Red Knight than on Paladin and CM-334 plants. By 4 days pi, necrotic lesions had formed on the taproot of Red Knight but not Paladin or CM-334 plants. Although hyphae were visible in the crowns and stems of all Red Knight plants observed at 4 days pi, hyphae were observed in crowns of only a few Paladin and in no CM-334 plants, and never in stems of either resistant cultivar at 4 days pi. These results improve our understanding of how $P$. capsici infects plants and may contribute to the use of resistant pepper cultivars for disease management and the development of new cultivars.
\end{abstract}

Although Phytophthora capsici is now known to infect many different vegetables, it was first identified on pepper (Capsicum annuum) (Granke et al. 2012; Leonian 1922). Wild pepper accessions with high levels of resistance to $P$. capsici have been identified, and this resistance has been bred into commercial pepper cultivars (Guerrero-Moreno and Laborde 1980; Kimble and Grogan 1960; Palloix et al. 1990; Peter et al. 1984; Saini and Sharma 1978). Previous investigations of the inheritance of resistance to $P$. capsici in pepper have indicated that several genes are likely involved in conferring resistance (Monroy-Barbosa and Bosland 2008; Ortega et al. 1991; Reifschneider et al. 1992), and that different genes may be associated with resistance to different symptoms such as root rot, fruit rot, and leaf lesions (Sy et al. 2005; Walker and Bosland 1999). More recent studies have focused on a major quantitative trait locus associated with resistance to $P$. capsici on chromosome 5 of pepper, and several genes on this chromosome have been identified as candidate resistance genes (Liu et al. 2014; Mallard et al. 2013; Rehrig et al. 2014). Criollos de Morelos line 334 (CM-334; also known as Serrano Criollos de Morelos) is a landrace derived from a wild pepper collected in Mexico (Guerrero-Moreno and Laborde 1980). It is highly resistant to root and crown rot caused by diverse isolates of $P$. capsici and is frequently used in pepper breeding programs or as a resistant control (Foster and Hausbeck 2010; Glosier et al. 2008; Guerrero-Moreno and Laborde 1980; Palloix et al. 1990). In addition, CM-334 is resistant to some potyviruses (Dogimont et al. 1996) and some nematode species (DjianCaporalino et al. 1999). Although the exact source of resistance is not known, the commercially available bell pepper 'Paladin' also has high levels of resistance to many isolates of $P$. capsici (Babadoost 2006; Dunn et al. 2014; Foster and Hausbeck 2010).

The physical interactions between some oomycete pathogens and plants have been studied with the hope of identifying the physical mechanisms underlying resistance or host specificity. These studies

Corresponding author: C. D. Smart; E-mail address: cds14@ cornell.edu

http://dx.doi.org/10.1094/PHYTO-02-15-0045-R

(C) 2015 The American Phytopathological Society have investigated a variety of aspects, including specific compounds which attract zoospores to roots (Morris and Ward 1992), ability of zoospores to attach to roots of host and nonhost plants (Enkerli et al. 1997; Mitchell and Deacon 1986), triggers for zoospore encystment (Benjamin and Newhook 1982), and the extent and timing of hyphal growth through host tissue (Enkerli et al. 1997). Previous work in the P. capsici-pepper pathosystem has focused on interactions at least $24 \mathrm{~h}$ after inoculation. Kim and Kim (2009) observed roots of susceptible ('Bugang') and resistant (CM334) pepper plants 1 and 3 days postinoculation (pi) with $P$. capsici. They found that pathogen hyphae were limited to the epidermal or cortical root tissue of CM-334 plants after 3 days, while hyphae had reached the vascular tissue of Bugang. Furthermore, thickening of the middle lamellae between cells, and cell wall appositions where hyphae contacted cells, appeared to block further hyphal growth in CM-334 plants. Lee et al. (2000) observed similar defense mechanisms in stem tissue of the susceptible pepper 'Hanbyul' $24 \mathrm{~h}$ after inoculation when plants were first treated with DL$\beta$-amino- $n$-butyric acid to induce resistance, or when plants were inoculated with a less virulent isolate of $P$. capsici. Hwang et al. (1989) also reported the formation of cell wall appositions where hyphae contacted host cells of Hanbyul roots; however, this did not halt infection, and hyphae were observed growing in xylem vessels 2 days pi. Although these studies did not utilize a green fluorescent protein (GFP)-tagged isolate of $P$. capsici, other pathogens constitutively expressing a gene for GFP have been useful in characterizing pathogen colonization of susceptible and resistant hosts (Njoroge et al. 2011; Vallad and Subbarao 2008). Previous studies utilizing fluorescently labeled $P$. capsici isolates have investigated pathogen effectors rather than host colonization (Schornack et al. 2010).

In other oomycetes, the relationship between early hostpathogen interactions and host resistance varies (Enkerli et al. 1997; Mitchell and Deacon 1986). Mitchell and Deacon (1986) showed that zoospores of two Pythium spp. pathogenic on grasses were less likely to encyst on wild nongrass species than on wild grass species, whereas zoospores of two generalist Pythium spp. encysted at similar frequencies on wild grass and nongrass species. 
However, this reduced encystment rate of grass-specific Pythium spp. was not observed on cultivated dicotyledonous plants (including tomato). Enkerli et al. (1997) investigated interactions of two P. sojae isolates with a resistant and a susceptible soybean cultivar, reporting no difference in zoospore encystment or germination on soybean roots between compatible and incompatible interactions. They did, however, observe differences beginning at $4 \mathrm{~h}$ pi.

This study investigated the physical interactions of $P$. capsic $i$ with resistant and susceptible pepper plants. The availability of a $P$. capsici isolate constitutively expressing a gene for GFP and similar to a wildtype isolate in virulence on pepper plants and fruit as well as in vitro growth facilitates this investigation (Dunn et al. 2013a). The goals of this project were to determine whether (i) the same number of P. capsici zoospores attach to and germinate on roots of a susceptible pepper cultivar ('Red Knight'), a resistant pepper cultivar ('Paladin'), and a resistant landrace (CM-334) and (ii) secondary root, crown, and stem tissues of Red Knight, Paladin, and CM-334 pepper plants are colonized by $P$. capsici with the same frequency.

\section{MATERIALS AND METHODS}

Plant material and culture. Landrace CM-334 and the commercially available bell pepper Paladin (Syngenta, Greensboro, NC) and Red Knight (Seminis, St. Louis) were used in all experiments. All plants were grown from untreated seed in a potting mixture (peat, perlite, and vermiculite in a 4:1:1 ratio) in 50-cell flats. Seed were germinated and plants were maintained in a greenhouse under natural and artificial light (16 h of light each day) and heat mats were used to improve germination. Throughout the following experiments, daily low and high temperature ranges were 14 to 16 and 22 to $42^{\circ} \mathrm{C}$, respectively. Five-week-old plants were used in all experiments.

Attachment (30 min pi) and germination (120 min pi) of $P$. capsici zoospores on pepper roots. Zoospore inoculum was prepared as previously described from 7-day-old cultures of P. capsici isolate PcapG-a (derived from NY 0664-1) that stably expresses a gene for GFP in all life stages (Dunn et al. 2013a). Isolate NY 0664-1 is a single-spore isolate collected in 2006 from a bell pepper plant at a commercial farm in central New York. It is sensitive to mefenoxam, representative of $P$. capsici isolates found in New York, and has been used to screen for resistance to $P$. capsici in the field over multiple years (Dunn et al. 2010, 2014). Potting mix was gently washed from the intact root system of a pepper plant, and the root system (still attached to the plant) was submerged in $40 \mathrm{ml}$ of a suspension of $1 \times 10^{4}$ zoospore/ml in a 50-ml Falcon tube (Corning, Corning, NY) and incubated at room temperature for $30 \mathrm{~min}$. At the end of this time, the root system was removed from the zoospore solution and dipped three times in sterile distilled water to wash off unattached zoospores. Three secondary or tertiary roots of each plant were arbitrarily selected and a $1-\mathrm{cm}$ piece was cut from the tip of each root. Images were collected using a confocal laser-scanning microscope (CLSM) system (Fluoview FV-300; Olympus, Melville, NY) connected to an Olympus BX61 microscope, as previously described (Hoch et al. 2005). Briefly, z-series images were collected from four 800- $\mu$ m-long sections of each 1$\mathrm{cm}$ root piece using the $\times 20$ objective. A green helium neon laser $(543 \mathrm{~nm})$ was used to elicit autofluorescence of the pepper roots and an argon laser (488 nm) was used to excite the enhanced GFP in the $P$. capsici isolate. Images were collected and assembled using the Fluoview software (Olympus) distributed with the CLSM system by compiling images taken at $2-\mu \mathrm{m}$ increments over a depth of $14 \mu \mathrm{m}$, which included the root surface and the area just above the surface. All root pieces were incubated at $4^{\circ} \mathrm{C}$ until images could be collected (within $1 \mathrm{~h}$ after they were cut from the plant) in order to slow zoospore germination and hyphal growth. The number of zoospores attached to the pepper root was summed among all four $\mathrm{Z}$-series images collected from each $1-\mathrm{cm}$ root piece. Three $1-\mathrm{cm}$ root pieces were examined from each plant and three plants were examined per cultivar, for a total of nine $1-\mathrm{cm}$ root pieces per cultivar. Root tips from plants of each cultivar not inoculated with P. capsici isolate PcapG-a were also examined using the CLSM to confirm the absence of structures that could have been mistaken for zoospores. The entire experiment was conducted twice (for a total of 18 root pieces per cultivar).

In order to quantify zoospore germination $120 \mathrm{~min}$ pi, roots from a separate set of plants (three plants per cultivar) were incubated for $30 \mathrm{~min}$ in $40 \mathrm{ml}$ of $1 \times 10^{4}$ zoospores $/ \mathrm{ml}$, as described above, with some adjustments. After dipping three times in sterile distilled water to remove unattached zoospores, the root systems (still attached to the plants) were incubated for an additional $90 \mathrm{~min}$ at room temperature in a sterile petri dish containing filter paper moistened with sterile distilled water (total of $120 \mathrm{~min} \mathrm{pi).} \mathrm{Three}$ secondary or tertiary roots were arbitrarily selected from each plant, and a $1-\mathrm{cm}$ piece was cut from the tip of each root. Four z-series images were taken of each root piece using a thicker $\mathrm{z}$-series $(26 \mu \mathrm{m}$ deep, with images taken at $2-\mu \mathrm{m}$ increments) to accommodate the hyphal growth that had occurred. Again, root pieces were incubated at $4^{\circ} \mathrm{C}$ until images could be collected (within $1 \mathrm{~h}$ after they were cut from the plant) in order to prevent further germination of zoospores. Three 1-cm root pieces were examined from each plant and three plants were examined per cultivar, for a total of nine root pieces per cultivar. Root tips from plants of each cultivar not inoculated with $P$. capsici isolate PcapG-a were also examined using the CLSM to confirm the absence of structures that could have been mistaken for zoospores. The entire experiment was conducted twice (for a total of 18 root pieces per cultivar).

Colonization of pepper roots and crowns by $\boldsymbol{P}$. capsici 3 days pi. Paladin, Red Knight, and CM-334 seedlings were grown in 50-cell flats, as described above. When seedlings were 5 weeks old, 10 plants per cultivar (only 8 plants of CM-334 in the first biological replicate and 10 in the second, due to limited seed availability and germination) were inoculated with $P$. capsici isolate PcapG-a. Prior to inoculation, seedlings were watered so that potting mix was near saturation, and the potting mix around the stem of each plant was then drenched with $3 \mathrm{ml}$ of a suspension of $1 \times 10^{5}$ zoospores $/ \mathrm{ml}$. Zoospore suspensions were produced as described above, and plants were incubated in the greenhouse following inoculation.

After 3 days, the potting mix was gently washed from the roots of half of the plants (four or five plants per cultivar). The total number of secondary roots attached to the taproot within $5 \mathrm{~mm}$ of the soil line and the number of these roots with brown lesions were counted on each plant. In addition, a mercury arc lamp and a fluorescein isothiocyanate (FITC) filter were used to visualize the presence or absence of $P$. capsici hyphae on each secondary root that had a brown lesion. The CLSM was used to collect representative images of colonized roots (over a 39- $\mu \mathrm{m} \mathrm{z}$-series, with images collected at $3-\mu \mathrm{m}$ increments), and the percentage of secondary roots with both brown lesions and hyphae was calculated. In addition, thin longitudinal sections of the crown tissue of each plant were made by hand ( 2 to $5 \mathrm{~mm}$ in length) and the mercury arc lamp, FITC filter, and the CLSM were used to visualize hyphae of $P$. capsici in the crown tissue. Images were collected over a $39-\mu \mathrm{m}$ z-series, with images collected at $3-\mu \mathrm{m}$ increments. Seedlings of each cultivar inoculated with $3 \mathrm{ml}$ of sterile distilled water (instead of $P$. capsici isolate PcapG-a) were also examined to confirm the absence of secondary root lesions or hyphae in crowns of noninoculated plants. The entire experiment was conducted twice (for a total of 9 or 10 plants per cultivar).

Colonization of pepper roots and crowns by $\boldsymbol{P}$. capsici 4 days pi. A new set of CM-334, Paladin, and Red Knight seedlings was grown exactly as described for the 3-day-pi time point but were examined 4 days pi. When seedlings were 5 weeks old, 10 plants per cultivar (only 8 plants of CM-334 in the first biological replicate and 10 in the second, due to limited seed availability and germination) were inoculated exactly as described for the 3-day-pi time point. After 4 days, potting mix was gently washed from the 
entire root system of four (CM-334) or five (Paladin and Red Knight) plants, and the length of the brown lesion on the taproot of each plant was measured. The entire experiment was conducted twice, with taproot lesions measured on five plants per cultivar in the second biological replicate, for a total of 9 (CM-334) or 10 (Paladin and Red Knight) plants per cultivar.

A new set of five plants per cultivar was inoculated in the same way in order to quantify colonization of the crown and stem tissue at 4 days pi. Cross-sections were made by hand at the soil line, $1 \mathrm{~cm}$ above the soil line, and $2 \mathrm{~cm}$ above the soil line of each plant and images were taken using the CLSM (over a $39-\mu \mathrm{m}$ z-series, with images collected at 3- $\mu \mathrm{m}$ increments). The presence of hyphae at each height in each plant was recorded, and the entire experiment was conducted twice (for a total of 10 plants per cultivar). Seedlings of each cultivar inoculated with $3 \mathrm{ml}$ of sterile distilled water were also examined 4 days pi to confirm the absence of secondary root lesions or hyphae in crowns of noninoculated plants.

Status of pepper plants 10 days pi. The remaining inoculated seedlings from the 3- and 4-day-pi experiments (four or five plants per cultivar from each biological replicate of each time point) were observed in the greenhouse until 10 days pi. Potting mix was gently washed from the roots of Paladin and CM-334 plants as described for the 3- and 4-day-pi time points. Taproots were checked for the presence of lesions, and hand sections of crown tissue from 9 (CM-334) or 10 (Paladin) plants per cultivar (representing 4 or 5 plants from each of two biological replicates) were checked for the presence of $P$. capsici hyphae using the mercury arc lamp, FITC filter, and CLSM.

Statistical analysis. All data were analyzed in SAS software (version 9.4; SAS Inc., Cary, NC). There were no significant $(P<$ $0.05)$ interactions between cultivar and biological replicate; therefore, data from both biological replicates were combined for analysis of zoospore attachment and germination (18 root pieces per cultivar), lesion development ( 9 or 10 plants per cultivar), colonization ( 9 or 10 plants per cultivar), and lesion length on taproots ( 9 or 10 plants per cultivar). Means across both biological replicates are reported. Normality of response variables was tested using a Shapiro-Wilk test. Number of zoospores attached per root $30 \mathrm{~min}$ pi and percentage of secondary roots with lesions were normally distributed and were analyzed using PROC GLIMMIX, with replication considered a random effect and cultivar considered a fixed effect. A least significant difference procedure was used to separate means. The assumption of normality was rejected $(P<0.05)$ for percentage of attached zoospores that had germinated $120 \mathrm{~min}$ pi, percentage of secondary roots with lesions and hyphae, and length of taproot lesion. A KruskalWallis test (using NPAR1WAY) was used to analyze these data, followed by a Bonferroni-Dunn test to separate means (Sheskin 1996).

\section{RESULTS}

Attachment and germination of $P$. capsici zoospores on pepper roots. At $30 \mathrm{~min}$ pi, there were no significant differences among cultivars in the number of $P$. capsici zoospores attached per root section $(P=0.58)$ (Table 1; Fig. 1A to $C)$. Interestingly, at this time point, some of the zoospores had already germinated (Fig. 1A to $\mathrm{C}$, arrows). By $120 \mathrm{~min}$ pi, nearly all of the attached zoospores had germinated on all pepper roots examined, and there were no significant differences among cultivars $(P=0.92)$ (Table 1; Fig. 1D to F). No zoospores were observed on the roots of noninoculated plants.

Root and crown colonization by $\boldsymbol{P}$. capsici. Three days after inoculation with $P$. capsici isolate PcapG-a, significantly more of the secondary roots attached to the taproot within $5 \mathrm{~mm}$ of the soil line had brown lesions on Red Knight plants compared with either Paladin or CM-334 plants (Table 2; Fig. 2A to C). However, the presence of macroscopic lesions on these roots was not necessarily associated with visible (via the CLSM) growth of $P$. capsici hyphae on the roots. Although hyphae were visible on most secondary roots with lesions from Red Knight plants, hyphae were visible on numerically fewer Paladin secondary roots with lesions (although not statistically significant) and significantly fewer CM-334 secondary roots (Table 2; Fig. 1G to I). GFP-tagged hyphae were visible in longitudinal sections of the crowns of all Red Knight plants at 3 days pi but none of the Paladin or CM-334 plants (Table 2). Lesions similar to those observed on the secondary roots of inoculated plants were not observed on noninoculated controls, and no hyphae were observed in longitudinal sections of crowns from noninoculated plants.

At 4 days pi, lesions on the taproot of Red Knight plants were significantly longer than on Paladin or CM-334 plants (on which no taproot lesions were observed) (Table 2; Fig. 2D to F). Hyphae were visible in all Red Knight plants at the crown and at $1 \mathrm{~cm}$ above the soil line (Fig. 3). In nearly all Red Knight plants, hyphae were also visible at $2 \mathrm{~cm}$ above the soil line (Table 2). In Paladin plants, hyphae were visible in the crowns of 2 of 10 plants and, on 1 of these plants, the crown tissue was beginning to shrivel, typical of $P$. capsici infection. However, no hyphae were observed at 1 or $2 \mathrm{~cm}$ above the soil line in any of the 10 Paladin plants. No hyphae were observed in the crown or stem tissue of the CM-334 plants (Table 2). Paladin and CM-334 crown and stem cross-sections in which no hyphae were observed resembled cross-sections from noninoculated plants. Lesions similar to those observed on the taproots of inoculated plants were not observed on noninoculated plants, and no hyphae were observed in cross-sections of crown or stem tissue of noninoculated plants.

By 10 days pi, Red Knight plants were completely dead (Fig. 2G); however, no hyphae were visible in the crowns of Paladin and CM334 plants. Although secondary roots with brown lesions were present on Paladin and CM-334 plants 10 days pi, new roots had grown, and no lesions were visible on the taproots of these plants (Fig. $2 \mathrm{H}$ and $\mathrm{I}$ ).

\section{DISCUSSION}

These experiments demonstrated that the resistance observed in Paladin bell pepper and the pepper landrace CM-334 to $P$. capsici isolate PcapG-a is not the result of the inability of zoospores of this isolate to attach to or germinate on plant roots within $120 \mathrm{~min}$ pi. Differences observed among susceptible and resistant cultivars in lesion formation and hyphal growth on secondary roots and taproots, as well as colonization of the crown and stem tissue, were consistent with previous studies of $P$. capsici interactions with resistant and susceptible pepper cultivars (Café-Filho and Duniway 1996; Hwang et al. 1989; Kim and Kim 2009; Lee et al. 2000). Kim and Kim (2009) and Lee et al. (2000) demonstrated that, in susceptible interactions, epidermal, cortical, and vascular tissues were colonized by the pathogen but, in resistant interactions, P. capsici generally did not reach the vascular tissue. Café-Filho and

TABLE 1. Attachment and germination of Phytophthora capsici zoospores on roots of three pepper cultivars 30 and $120 \mathrm{~min}$ postinoculation (pi), respectivelyw

\begin{tabular}{|c|c|c|c|c|c|}
\hline \multirow[b]{2}{*}{ Cultivar } & \multirow[b]{2}{*}{$N^{\mathrm{z}}$} & \multicolumn{2}{|c|}{$\begin{array}{c}\text { Zoospores } \\
\text { attached } \\
(30 \text { min pi })^{x}\end{array}$} & \multicolumn{2}{|c|}{$\begin{array}{c}\text { Attached zoospores } \\
\text { germinated } \\
\left(120 \text { min pi) }(\%)^{\mathrm{y}}\right.\end{array}$} \\
\hline & & Mean & $\mathrm{SE}$ & Mean & SE \\
\hline Red Knight & 18 & $60 \mathrm{a}$ & 7 & $98.6 \mathrm{a}$ & 0.59 \\
\hline Paladin & 18 & $59 \mathrm{a}$ & 8 & $99.1 \mathrm{a}$ & 0.34 \\
\hline CM-334 & 18 & $51 \mathrm{a}$ & 6 & $98.6 \mathrm{a}$ & 0.60 \\
\hline
\end{tabular}

${ }^{\mathrm{w}}$ All data shown are combined from two biological replicates; SE = standard error.

${ }^{x}$ Number of zoospores attached per root section 30 min pi. Means followed by the same letter are not significantly different (least significant difference; $P=0.05)$

y Percentage of attached zoospores that had germinated (per root section) 120 min pi. Means followed by the same letter are not significantly different (Bonferroni-Dunn; $P=0.05$ ).

$\mathrm{z}$ Total number of root sections observed per cultivar. 
Duniway (1996) observed lesions on the roots of both susceptible ('Yolo Wonder') and resistant ('Adra') pepper cultivars following inoculation with $P$. capsici zoospores. Lesions on Adra roots grew more slowly and their rate of expansion decreased over time compared with lesions on Yolo Wonder roots, and lesions never reached the crown of Adra plants.
Similar patterns of root colonization between resistant and susceptible crops have been documented for other soilborne pathogens and pests. In the P. sojae-soybean interaction, Enkerli et al. (1997) reported that the pathogen colonized the entire root (including the vascular tissue) of a susceptible soybean cultivar but not of a resistant cultivar. Vallad and Subbarao (2008) found no
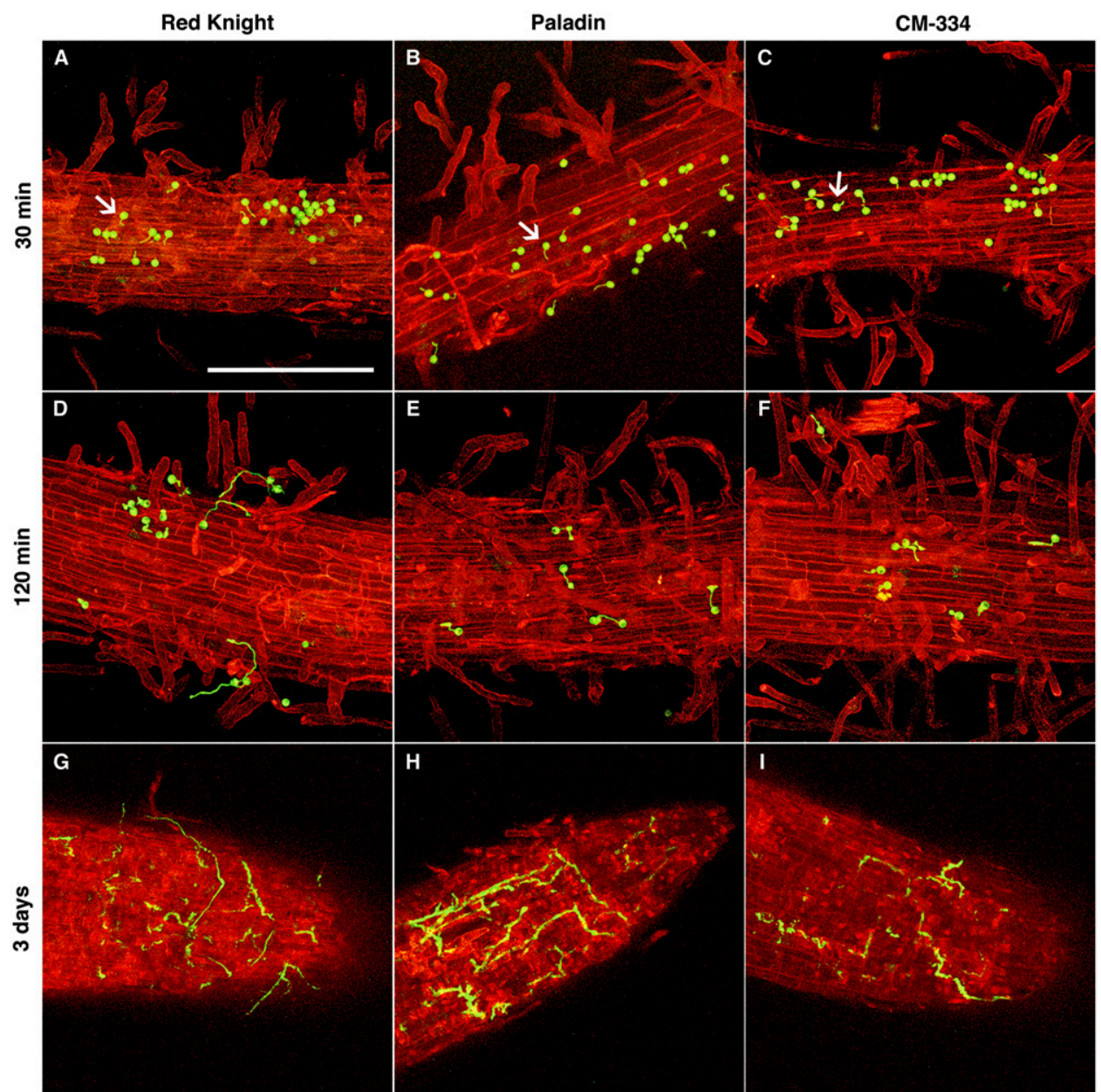

Fig. 1. A-C, Zoospore attachment; D-F, germination; and G-I, root tip colonization of a green fluorescent protein-tagged isolate of Phytophthora capsici on pepper roots of susceptible 'Red Knight' (A, D, and G), resistant 'Paladin' (B, E, and H), and resistant landrace CM-334 (C, F, and I) plants. Images were collected with a confocal laser-scanning microscope $30 \mathrm{~min}$ (zoospore attachment, A-C), $120 \mathrm{~min}$ (zoospore germination, D-F), or 3 days (hyphal growth on secondary root tips with brown lesions, G-I) postinoculation (pi). Some zoospores had already germinated by $30 \mathrm{~min}$ pi, as indicated by white arrows (A-C). Scale bar represents $200 \mu \mathrm{m}$, and is the same for all images.

TABLE 2. Colonization of roots of three pepper cultivars by Phytophthora capsici 3 and 4 days postinoculation (pi) ${ }^{\mathrm{s}}$

\begin{tabular}{|c|c|c|c|c|c|c|c|c|c|c|c|c|}
\hline \multirow[b]{3}{*}{ Cultivar } & \multicolumn{7}{|c|}{3 days pi } & \multicolumn{5}{|c|}{4 days pi } \\
\hline & \multirow[b]{2}{*}{$N^{\mathrm{x}}$} & \multirow[b]{2}{*}{ Roots $^{y}$} & \multicolumn{2}{|c|}{$\begin{array}{l}\text { Roots with } \\
\text { lesions }(\%)^{\mathrm{t}}\end{array}$} & \multicolumn{2}{|c|}{$\begin{array}{c}\text { Lesions } \\
\text { colonized }(\%)^{\mathrm{u}}\end{array}$} & \multirow[b]{2}{*}{ Hyphae $(n)^{\mathrm{z}}$} & \multicolumn{2}{|c|}{$\begin{array}{l}\text { Taproot lesion } \\
\text { length }(\mathrm{mm})^{\mathrm{v}}\end{array}$} & \multicolumn{3}{|c|}{$\begin{array}{l}\text { Hyphae in crown } \\
\text { and stem }(n)^{\mathrm{w}}\end{array}$} \\
\hline & & & Mean & SE & Mean & SE & & Mean & SE & Crown & $1 \mathrm{~cm}$ & $2 \mathrm{~cm}$ \\
\hline Red Knight & 10 & 236 & $63.1 \mathrm{a}$ & 5.66 & $87.5 \mathrm{a}$ & 4.89 & 10 & $10.7 \mathrm{a}$ & 1.13 & 10 & 10 & 9 \\
\hline Paladin & 10 & 192 & $34.5 \mathrm{~b}$ & 5.51 & $57.5 \mathrm{ab}$ & 8.17 & 0 & $0 \mathrm{~b}$ & 0 & 2 & 0 & 0 \\
\hline CM-334 & 9 & 245 & $24.2 \mathrm{~b}$ & 4.12 & $41.5 \mathrm{~b}$ & 11.20 & 0 & $0 \mathrm{~b}$ & 0 & 0 & 0 & 0 \\
\hline
\end{tabular}

s All data shown are combined from two biological replicates; $\mathrm{SE}=$ standard error.

${ }^{t}$ Percentage (per plant) of secondary roots attached to taproot within $5 \mathrm{~mm}$ of the soil line that had brown lesions 3 days pi; means followed by the same letter are not significantly different (least significant difference; $P=0.05$ )

" Percentage (per plant) of roots with lesions and on which $P$. capsici hyphae were visible using the confocal laser-scanning microscope; means followed by the same letter are not significantly different (Bonferroni-Dunn; $P=0.05$ ).

${ }^{v}$ Length of lesions $(\mathrm{mm})$ observed on taproot of plants 4 days pi; means followed by the same letter are not significantly different (Bonferroni-Dunn; $P=0.05$ ).

${ }^{w}$ Number of plants per cultivar in which hyphae were observed in cross-sections of crown and stem ( 1 and $2 \mathrm{~cm}$ above the soil line) tissue. Ten plants were observed per cultivar.

${ }^{x}$ Total number of plants observed per cultivar.

y Total number of roots observed per cultivar 3 days pi.

${ }^{z}$ Hyphae in crown: number of plants per cultivar in which hyphae were observed in longitudinal sections of crown tissue 3 days pi. 
difference in the initial colonization of lettuce cultivars that differed in resistance to Verticillium dahliae up to 2 weeks pi. In resistant lettuce plants, $V$. dahliae colonized cortical tissue and penetrated vascular tissue but never progressed beyond lateral roots to the taproot. Similarly, Njoroge et al. (2011) demonstrated that $V$. dahliae successfully colonized the vascular system of the entire cauliflower plant (susceptible to $V$. dahliae) but rarely colonized vascular tissue of broccoli plants (resistant to V. dahliae). Pegard et al. (2005) made similar observations in the (resistant) interaction between CM-334 pepper and root-knot nematodes (Meloidogyne spp.). Fewer second-stage juvenile nematodes were able to penetrate the roots of CM-334 compared with a susceptible pepper, and nematodes never progressed to the vascular tissue of the pepper roots. Based on these similarities across soilborne pathogens, common plant defense mechanisms may be involved in limiting colonization of resistant cultivars.

Previous studies have suggested that cell wall appositions play an important role in limiting colonization of resistant hosts by soilborne pathogens. Kim and Kim (2009) and Lee et al. (2000) reported that cell wall appositions blocked further growth of $P$. capsici in resistant pepper roots and stems, respectively. However, Hwang et al. (1989) also observed cell wall appositions in a susceptible pepper interaction which were clearly not able to halt spread of the pathogen. In the $P$. sojae-soybean pathosystem, Enkerli et al. (1997) also reported fewer cell wall appositions in compatible interactions compared with incompatible interactions. In our study, cell wall appositions could not be visualized using the CLSM, nor was the presence or absence of cell wall appositions noted in CLSM studies of interactions between $V$. dahliae and broccoli, cauliflower, or lettuce (Njoroge et al. 2011; Vallad and Subbarao 2008).

Enkerli et al. (1997) also attributed host resistance in incompatible interactions to early detection of the pathogen by the plant, marked by host cell necrosis as early as $4 \mathrm{~h}$ pi. During compatible interactions, $P$. sojae grew biotrophically in the host for 7 to $10 \mathrm{~h}$ pi before host cell necrosis began in the outer cell layers of the root. Pegard et al. (2005) also reported that host necrosis was involved in limiting colonization of CM-334 by Meloidogyne spp. It is important to note that Enkerli et al. (1997) studied an interaction governed by gene-for-gene resistance (two races of $P$. sojae and two soybean isolines, each with a specific resistance gene matching one
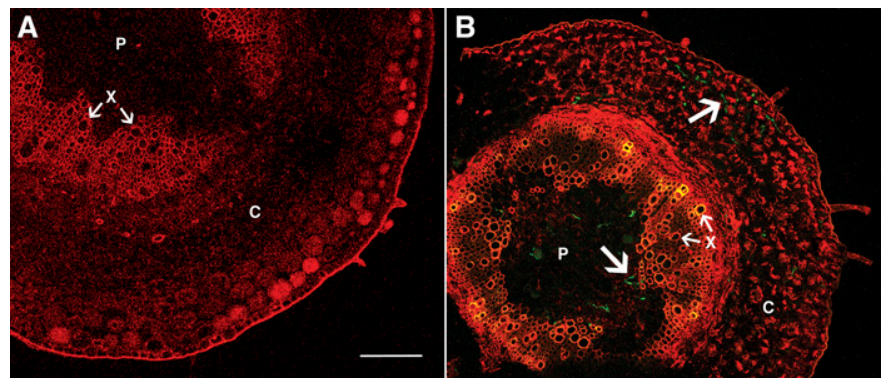

Fig. 3. Stem cross sections taken $1 \mathrm{~cm}$ above the soil line of a 'Red Knight' plant 4 days after inoculation with $\mathbf{A}$, sterile distilled water or $\mathbf{B}$, a green fluorescent protein-tagged isolate of Phytophthora capsici. Hyphae of $P$. capsici are visible throughout the stem of the inoculated plant (examples marked with large arrows). Cortex (C), xylem vessels (X), and pith (P) are labeled. Scale bar represents $200 \mu \mathrm{m}$ and is the same for both images.

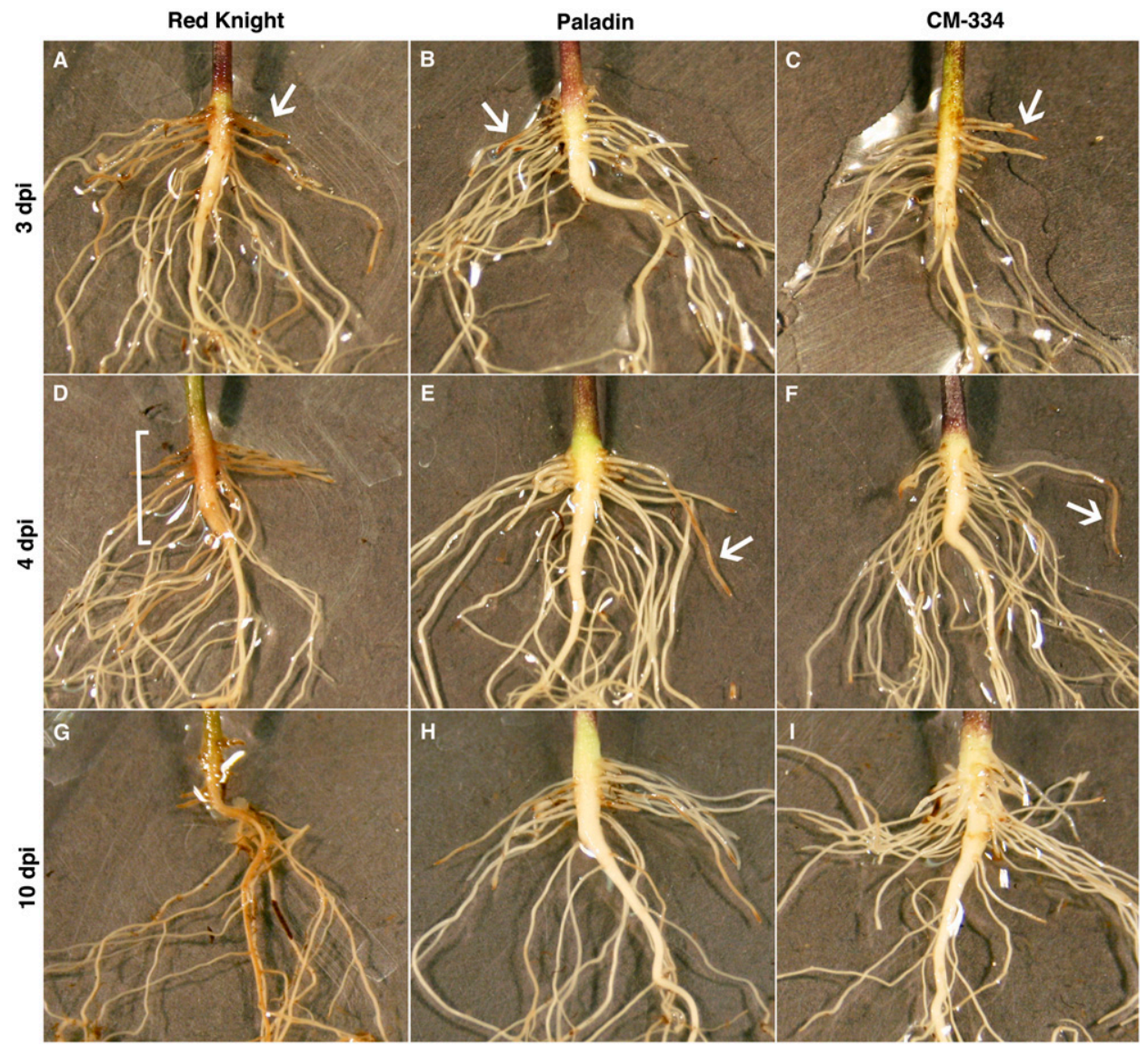

Fig. 2. Roots of susceptible 'Red Knight', resistant 'Paladin', and resistant landrace CM-334 pepper plants A-C, 3; D-F, 4; or G-I, 10 days postinoculation (dpi) with Phytophthora capsici. The number of secondary roots attached to the taproot within $5 \mathrm{~mm}$ of the soil line and having brown lesions (white arrows) were counted at 3 dpi (A-C). Lesions on the taproot were only observed on Red Knight plants and the lengths of these lesions (white bracket) were measured 4 dpi (D-F). Secondary roots with lesions were still present on Paladin and CM-334 plants (white arrows; E and F). By 10 dpi, all parts of the root systems of Red Knight (G) plants were necrotic but necrosis had not progressed on the root systems of Paladin (H) and CM-334 (I) plants and no lesions were present on the taproots. 
of the $P$. sojae races). If specific plant resistance genes and corresponding pathogen avirulence genes are involved in the resistance of either CM-334 or Paladin to $P$. capsici isolate PcapGa (derived from NY 0664-1) used in this study, they have not yet been described. The fact that secondary roots of CM-334 and Paladin plants still had some lesions but that fewer of these roots with lesions also had visible hyphae (compared with the majority of the Red Knight secondary roots with lesions) suggests that a hypersensitive response could be involved in the ability of CM334 and Paladin to resist infection by this isolate of $P$. capsici. This would be consistent with the ability of CM-334 and Paladin plants to recognize certain $P$. capsici effectors, which Red Knight plants are unable to recognize. Similar to other Phytophthora spp., the $P$. capsici genome includes numerous effector genes (Lamour et al. 2012), some of which are expressed at different stages of infection (Feng et al. 2014).

Variation among these three cultivars in production of plant defense compounds in response to $P$. capsici isolate PcapG-a is another possible explanation of differences in pepper susceptibility. In the $V$. dahliae-broccoli pathosystem, Njoroge et al. (2011) attributed host resistance to increased production of phenolic compounds and lignin, as well as the sensitivity of $V$. dahliae to the specific glucosinolates produced by broccoli. Pegard et al. (2005) also provided evidence that phenolic compounds produced by CM-334 were involved in resistance of this pepper landrace to Meloidogyne spp. Giannakopoulou et al. (2014) reported that $P$. capsici was less sensitive to the pepper phytoalexin capsidiol than was $P$. infestans (to which pepper are not susceptible). Others have demonstrated reduced capsidiol accumulation in susceptible pepper cultivars compared with a resistant cultivar (Egea et al. 1996; Hwang and Sung 1989). Requena et al. (2005) reported an increased production of nitric oxide in CM-334 plants compared with a susceptible pepper cultivar following either inoculation with $P$. capsici or wounding, noting that the increased nitric oxide production seemed to be involved in halting further colonization of CM-334 plants by $P$. capsici hyphae following some initial growth from the inoculation site. Future studies may elucidate the role of these (or other) defense compounds in limiting root, crown, and stem colonization of resistant pepper plants by $P$. capsici following attachment and germination of zoospores.

Previous studies have demonstrated that Paladin bell pepper is not resistant to all isolates of $P$. capsici (Foster and Hausbeck 2010; McGrath and Fox 2009; Yin et al. 2012). Furthermore, under highly conducive conditions (saturated soil, warm temperatures, and high levels of inoculum), low levels of disease incidence may result even from isolates to which the cultivar is generally resistant, including NY 0664-1, the isolate from which PcapG-a was derived (Dunn et al. 2014). Thus, interactions between $P$. capsici and different pepper cultivars may vary based on the isolate used, the quantity of inoculum, and the environmental conditions. In this study, colonization of the roots, crown, and stem but not attachment and germination of zoospores differed between bell pepper cultivars known to be susceptible or resistant to one isolate of $P$. capsici. This isolate was selected because its virulence on bell pepper cultivars has been well characterized (Dunn et al. 2014) and because it had been transformed to constitutively express a gene for GFP (Dunn et al. 2013a). Fluorescent labeling of additional P. capsici isolates representing a range of aggressiveness on pepper cultivars and the use of additional inoculum concentrations could enhance our understanding of the early interactions between pepper plants and $P$. capsici in the future.

The use of resistant cultivars is currently a key component of successfully managing $P$. capsici in bell pepper. However, not all currently available resistant cultivars have optimal horticultural traits (Dunn et al. 2013b; Kline et al. 2011). Furthermore, some isolates of $P$. capsici can still infect "resistant" cultivars such as Paladin and it is likely that, over time, populations of $P$. capsic $i$ will adapt to overcome resistance in more of the currently available bell pepper cultivars (Foster and Hausbeck 2010; McGrath and Fox 2009; Yin et al. 2012). It is not clear what host or pathogen genes are involved when host resistance is overcome, or what mechanism underlies susceptibility of "resistant" cultivars under high disease pressure. In addition, no commercial resistant cultivars are currently available for other solanaceous or cucurbitaceous hosts of $P$. capsici. For these reasons, breeding for resistance to $P$. capsici in all of its vegetable hosts will continue to be a high priority. This study advances our understanding of how a well-characterized isolate of $P$. capsici interacts differently with resistant and susceptible host plants. Continued use of fluorescently labeled $P$. capsici isolates will enhance our understanding of the mechanisms underlying host resistance to $P$. capsici, facilitate the breeding of additional resistant cultivars, and enable optimal use of these cultivars within an integrated vegetable disease management strategy.

\section{ACKNOWLEDGMENTS}

This project was supported by the Agriculture and Food Research Initiative Competitive Grant Number 2012-67011-19690 from the United States Department of Agriculture National Institute of Food and Agriculture, and by the New York State Department of Agriculture and Markets through an NY Specialty Crops Block Grant. Support for A.R. Dunn was also provided by a fellowship from Cornell University College of Agriculture and Life Sciences. We thank H. C. Hoch for assistance with the confocal laser-scanning microscope.

\section{LITERATURE CITED}

Babadoost, M. 2006. Performance of bell pepper cultivars in a commercial field infested with Phytophthora capsici. HortScience 41:981.

Benjamin, M., and Newhook, F. J. 1982. Effect of glass microbeads on Phytophthora zoospore motility. Trans. Br. Mycol. Soc. 78:43-46.

Café-Filho, A. C., and Duniway, J. M. 1996. Effect of location of drip irrigation emitters and position of Phytophthora capsici infections in roots on Phytophthora root rot of pepper. Plant Dis. 86:1364-1369.

Djian-Caporalino, C., Pijarowski, L., Januel, A., Lefebvre, V., Daubéze, A., Palloix, A., Dalmasso, A., and Abad, P. 1999. Spectrum of resistance to root-knot nematodes and inheritance of heat-stable resistance in pepper (Capsicum annuum L.). Theor. Appl. Genet. 99:496-502.

Dogimont, C., Palloix, A., Daubze, A.-M., Marchoux, G., Selassie, K. G., and Pochard, E. 1996. Genetic analysis of broad spectrum resistance to potyviruses using doubled haploid lines of pepper (Capsicum annиит L.). Euphytica 88:231-239.

Dunn, A. R., Fry, B. A., Lee, T. Y., Conley, K. D., Balaji, V., Fry, W. E., McLeod, A., and Smart, C. D. 2013a. Transformation of Phytophthora capsici with genes for green and red fluorescent protein for use in visualizing plant-pathogen interactions. Australas. Plant Pathol. 42:583-593.

Dunn, A. R., Lange, H. W., and Smart, C. D. 2014. Evaluation of commercial bell pepper cultivars for resistance to Phytophthora blight (Phytophthora capsici). Plant Health Prog. 15:19-24.

Dunn, A. R., Milgroom, M. G., Meitz, J. C., McLeod, A., Fry, W. E., McGrath, M. T., Dillard, H. R., and Smart, C. D. 2010. Population structure and resistance to mefenoxam of Phytophthora capsici in New York State. Plant Dis. 94:1461-1468.

Dunn, A. R., Wyatt, L. E., Mazourek, M., Reiners, S., and Smart, C. D. 2013b. Performance and tolerance to Phytophthora blight of bell pepper varieties. HortTechnology 23:382-390.

Egea, C., García-Pérez, M. D., and Candela, M. E. 1996. Capsidiol accumulation in Capsicum annuum stems during the hypersensitive reaction to Phytophthora capsici. J. Plant Physiol. 149:762-764.

Enkerli, K., Hahn, M. G., and Mims, C. W. 1997. Ultrastructure of compatible and incompatible interactions of soybean roots infected with the plant pathogenic oomycete Phytophthora sojae. Can. J. Bot. 75:1493-1508.

Feng, B.-Z., Zhu, X.-P., Fu, L., Lv, R.-F., Storey, D., Tooley, P., and Zhang, X.-G. 2014. Characterization of necrosis-inducing NLP proteins in Phytophthora capsici. BMC Plant Biol. 14:126.

Foster, J. M., and Hausbeck, M. K. 2010. Resistance of pepper to Phytophthora crown, root, and fruit rot is affected by isolate virulence. Plant Dis. 94: 24-30.

Giannakopoulou, A., Schornack, S., Bozkurt, T. O., Haart, D., Ro, D.-K., Faraldos, J. A., Kamoun, S., and O'Maille, P. E. 2014. Variation in capsidiol sensitivity between Phytophthora infestans and Phytophthora capsici is consistent with their host range. PLoS One 9:e107462. 
Glosier, B. R., Ogundiwin, E. A., Sidhu, G. S., Sischo, D. R., and Prince, J. P. 2008. A differential series of pepper (Capsicum annuum) lines delineates fourteen physiological races of Phytophthora capsici. Euphytica 162:23-30.

Granke, L. L., Quesada-Ocampo, L. M., Lamour, K., and Hausbeck, M. 2012. Advances in research on Phytophthora capsici on vegetable crops in the United States. Plant Dis. 96:1588-1600.

Guerrero-Moreno, A., and Laborde, J. A. 1980. Current status of pepper breeding for resistance to Phytophthora capsici in Mexico. Pages 52-56 in: Proc. IVth Meet. Eucarpia Capsicum Work. Group, Wageningen, The Netherlands.

Hoch, H., Galvani, C., Szarowski, D., and Turner, J. 2005. Two new fluorescent dyes applicable for visualization of fungal cell walls. Mycologia 97:580-588.

Hwang, B., Kim, W. B., and Kim, W. K. 1989. Ultrastructure at the hostparasite interface of Phytophthora capsici in roots and stems of Capsicum annuum. J. Phytopathol. 127:305-315.

Hwang, B. K., and Sung, N. K. 1989. Effect of metalaxyl on capsidiol production in stems of pepper plants infected with Phytophthora capsici. Plant Dis. 73:748-751.

Kim, S. G., and Kim, Y. H. 2009. Histological and cytological changes associated with susceptible and resistant responses of chili pepper root and stem to Phytophthora capsici infection. Plant Pathol. J. 25:113-120.

Kimble, K. A., and Grogan, R. G. 1960. Resistance to Phytophthora root rot in pepper. Plant Dis. 50:642.

Kline, W. L., Wyenandt, C. A., Ward, D. L., Sudal, J. F., and Maxwell, N. L. 2011. Evaluation of six nitrogen fertility programs on marketable yield and development of skin separation in bell pepper fruit. HortTechnology 21:323-328.

Lamour, K. H., Mudge, J., Gobena, D., Hurtado-Gonzales, O. P., Schmutz, J., Kuo, A., Miller, N. A., Rice, B. J., Raffaele, S., Cano, L. M., Bharti, A. K., Donahoo, R. S., Finley, S., Huitema, E., Hulvey, J., Platt, D., Salamov, A., Savidor, A., Sharma, R., Stam, R., Storey, D., Thines, M., Win, J., Haas, B. J., Dinwiddie, D. L., Jenkins, J., Knight, J. R., Affourtit, J. P., Han, C. S., Chertkov, O., Lindquist, E. A., Detter, C., Grigoriev, I. V., Kamoun, S., and Kingsmore, S. F. 2012. Genome sequencing and mapping reveal loss of heterozygosity as a mechanism for rapid adaptation in the vegetable pathogen Phytophthora capsici. Mol. Plant-Microbe Interact. 25:1350-1360.

Lee, Y., Hong, J., Hippe-Sanwald, S., and Hwang, B. 2000. Histological and ultrastructural comparisons of compatible, incompatible and DL- $\beta$-amino$n$-butyric acid-induced resistance responses of pepper stems to Phytophthora capsici. Physiol. Mol. Plant Pathol. 57:269-280.

Leonian, L. H. 1922. Stem and fruit blight of peppers caused by Phytophthora capsici sp. nov. Plant Dis. 12:401-408.

Liu, W.-Y., Kang, J.-H., Jeong, H.-S., Choi, H.-J., Yang, H.-B., Kim, K.-T., Choi, D., Choi, G. J., Jahn, M., and Kang, B.-C. 2014. Combined use of bulked segregant analysis and microarrays reveals SNP markers pinpointing a major QTL for resistance to Phytophthora capsici in pepper. Theor. Appl. Genet. 127:2503-2513.

Mallard, S., Cantet, M., Massire, A., Bachellez, A., Ewert, S., and Lefebvre, V. 2013. A key QTL cluster is conserved among accessions and exhibits broad-spectrum resistance to Phytophthora capsici: A valuable locus for pepper breeding. Mol. Breed. 32:349-364.

McGrath, M. T., and Fox, G. M. 2009. Evaluation of Phytophthora-resistant bell pepper cultivars with and without a fungicide program, 2008. Plant Dis. Manage. Rep. 3:V016.

Mitchell, R. T., and Deacon, J. W. 1986. Differential (host-specific) accumulation of zoospores of Pythium on roots of graminaceous and nongraminaceous plants. New Phytol. 102:113-122.
Monroy-Barbosa, A., and Bosland, P. W. 2008. Genetic analysis of Phytophthora root rot race-specific resistance in Chile pepper. J. Am. Soc. Hortic. Sci. 133:825-829.

Morris, P. F., and Ward, E. W. B. 1992. Chemoattraction of zoospores of the soybean pathogen, Phytophthora sojae, by isoflavones. Physiol. Mol. Plant Pathol. 40:17-22.

Njoroge, S. M. C., Vallad, G. E., Park, S.-Y., Kang, S., Koike, S. T., Bolda, M., Burman, P., Polonik, W., and Subbarao, K. V. 2011. Phenological and phytochemical changes correlate with differential interactions of Verticillium dahliae with broccoli and cauliflower. Plant Dis. 101:523-534.

Ortega, R. G., Espanol, C. P., and Zueco, J. C. 1991. Genetics of resistance to Phytophthora capsici in the pepper line SCM-334. Plant Breed. 107:50-55.

Palloix, A., Daubeze, A. M., Phaly, T., and Pochard, E. 1990. Breeding transgressive lines of pepper for resistance to Phytophthora capsici in a recurrent selection system. Euphytica 51:141-150.

Pegard, A., Brizzard, G., Fazari, A., Soucaze, O., Abad, P., and DjianCaporalino, C. 2005. Histological characterization of resistance to different root-knot nematode species related to phenolics accumulation in Capsicum annuum. Annu. Rev. Phytopathol. 95:158-165.

Peter, K. V., Goth, R. W., and Webb, R. E. 1984. Indian hot peppers as new sources of resistance to bacterial wilt, Phytophthora root rot, and root knot nematode. HortScience 19:277-278.

Rehrig, W. Z., Ashrafi, H., Hill, T., Prince, J., and Van Deynze, A. 2014. CaDMR1 cosegregates with QTL Pc5.1 for resistance to Phytophthora capsici in Pepper (Capsicum annuum). Online publication. Plant Genome 7(2). https:// dl.sciencesocieties.org/publications/tpg/abstracts/7/2/plantgenome2014.03.0011

Reifschneider, F. J. B., Boiteux, L. S., Dellavecchia, P. T., Poulos, J. M., and Kuroda, N. 1992. Inheritance of adult-plant resistance to Phytophthora capsici in pepper. Euphytica 62:45-49.

Requena, M. E., Egea-Gilabert, C., and Candela, M. E. 2005. Nitric oxide generation during the interaction with Phytophthora capsici of two Capsicum annuиm varieties showing different degrees of sensitivity. Physiol. Plant. 124:50-60.

Saini, S. S., and Sharma, P. P. 1978. Inheritance of resistance to fruit rot (Phytophthora capsici Leon.) and induction of resistance in bell pepper (Capsicum annuum L.). Euphytica 27:721-723.

Schornack, S., van Damme, M., Bozkurt, T. O., Cano, L., Smoker, M., Thines, M., Gaulin, E., Kamoun, S., and Huitema, E. 2010. Ancient class of translocated oomycete effectors targets the host nucleus. Proc. Natl. Acad. Sci. USA 107:17421-17426.

Sheskin, D. J. 1996. Handbook of Parametric and Nonparametric Statistical Procedures. CRC Press, Boca Raton, FL.

Sy, O., Bosland, P. W., and Steiner, R. 2005. Inheritance of Phytophthora stem blight resistance as compared to Phytophthora root rot and Phytophthora foliar blight resistance in Capsicum annuum L. J. Am. Soc. Hortic. Sci. 130: 75-78.

Vallad, G. E., and Subbarao, K. V. 2008. Colonization of resistant and susceptible lettuce cultivars by a green fluorescent protein-tagged isolate of Verticillium dahliae. Plant Dis. 98:871-885.

Walker, S. J., and Bosland, P. W. 1999. Inheritance of Phytophthora root rot and foliar blight resistance in pepper. J. Am. Soc. Hortic. Sci. 124:14-18.

Yin, J., Jackson, K. L., Candole, B. L., Csinos, A. S., Langston, D. B., and Ji, P. 2012. Aggressiveness and diversity of Phytophthora capsici on vegetable crops in Georgia. Ann. Appl. Biol. 160:191-200. 